\title{
Changes in body core and body surface temperatures during prolonged swimming in water of $10^{\circ} \mathrm{C}$-a case report
}

\author{
Christoph Alexander Rüst ${ }^{1}$, Beat Knechtle ${ }^{1,2^{*}}$ and Thomas Rosemann ${ }^{1}$
}

\begin{abstract}
Background: This case report describes an experienced open-water ultra-endurance athlete swimming in water of $9.9^{\circ} \mathrm{C}$ for $6 \mathrm{~h}$ and $2 \mathrm{~min}$.

Methods: Before the swim, anthropometric characteristics such as body mass, body height, skinfold thicknesses, and body fat were determined. During and after the swim, body core (rectum) and body surface (forearm and calf) temperatures were continuously recorded.

Results: The swimmer (53 years old, $110.5 \mathrm{~kg}$ body mass, $1.76 \mathrm{~m}$ body height, $34.9 \%$ body fat, and a body mass index of $35.7 \mathrm{~kg} / \mathrm{m}^{2}$ ) achieved a total distance of $15 \mathrm{~km}$ while swimming at a mean speed of $2.48 \mathrm{~km} / \mathrm{h}$, equal to $0.69 \mathrm{~m} / \mathrm{s}$, in water of $9.9^{\circ} \mathrm{C}$. Body core temperature was at $37.8^{\circ} \mathrm{C}$ before the swim, increased to a maximum of $38.1^{\circ} \mathrm{C}$ after approximately 20 min of swimming, and then decreased continuously to $36.3^{\circ} \mathrm{C}$ upon finishing the swim. The lowest body core temperature was $36.0^{\circ} \mathrm{C}$ between 35 and 60 min after finishing the swim. Sixty minutes after the swim, the body core temperature continuously rose to $36.5^{\circ} \mathrm{C}$ where it remained. At the forearm, the temperature dropped to $19.6^{\circ} \mathrm{C}$ after approximately $36 \mathrm{~min}$ of swimming and decreased to $19.4^{\circ} \mathrm{C}$ by the end of the swim. The lowest temperature at the forearm was $17.6^{\circ} \mathrm{C}$ measured at approximately 47 min before the athlete stopped swimming. At the calf, the temperature dropped to $13.0^{\circ} \mathrm{C}$ after approximately 24 min of swimming and decreased to $11.9^{\circ} \mathrm{C}$ at the end of the swim. The lowest temperature measured at the calf was $11.1^{\circ} \mathrm{C}$ approximately 108 min after the start. In both the forearm and the calf, the skin temperature continuously increased after the swim.

Conclusions: This case report shows that (1) it is possible to swim for $6 \mathrm{~h}$ in water of $9.9^{\circ} \mathrm{C}$ and that (2) the athlete did not suffer from hypothermia under these circumstances. The high body mass index, high body fat, previous experience, and specific preparation of the swimmer are the most probable explanations for these findings.
\end{abstract}

Keywords: Hypothermia, Afterdrop, Body fat, Skinfold thickness, Open-water swimming

\section{Background}

Athletes strive to push the limits of human performance. In indoor pool swimming, athletes try to swim as fast as possible [1] or to achieve as many kilometers as possible in ultra-swimming [2]. Another challenge for open-water swimmers is to swim as long as possible in cold water [3-9]. To date, the lowest reported water temperature in a scientific study in open-water swimming was $4^{\circ} \mathrm{C}$ where a

\footnotetext{
* Correspondence: beat.knechtle@hispeed.ch

${ }^{1}$ Institute of General Practice and for Health Services Research, University of Zurich, Zurich, Switzerland

${ }^{2}$ Gesundheitszentrum St. Gallen, Vadianstrasse 26, St. Gallen 9001, Switzerland
}

swimmer was able to achieve a swim distance of $2.2 \mathrm{~km}$ within 42 min under this condition [7]. In 1969, Keatinge et al. [5] reported that two men were able to swim in water of $4.7^{\circ} \mathrm{C}$ for 1.5 and $7.6 \mathrm{~min}$, respectively. At higher temperatures, swimmers were able to stay longer in open water. In the 'New Year's Day Alcatraz Swim', 11 swimmers were able to complete the $3-\mathrm{km}$ swim between 31.3 and $62.6 \mathrm{~min}$ while swimming in $11.7^{\circ} \mathrm{C}$ cold water [8]. In an experiment, ten volunteers undertook three self-paced breaststroke swims in water at $25^{\circ} \mathrm{C}, 18^{\circ} \mathrm{C}$, and $10^{\circ} \mathrm{C}$ where one swimmer had to quit after $61 \mathrm{~min}$ and four swimmers stopped before $90 \mathrm{~min}$ [9]. In a 92-km relay

\section{Biomed Central}


swim in Finnish lakes, eight swimmers experienced cold water swimming and achieved a mean swim time of 52.3 min in water with a mean temperature of $10.2^{\circ} \mathrm{C}$ [6]. In 1955, Pugh and Edholm reported from a swimming race across the English Channel where 18 of 20 participants completed the distance between France and England within 12 to $20 \mathrm{~h}$ in water of $15.5^{\circ} \mathrm{C}$ [10]. This was an interesting finding since records of shipwreck survivors showed that men can survive in the ocean at $15.5^{\circ} \mathrm{C}$ only for about $5 \mathrm{~h}$ [11]. Tolerance to water at temperatures below $20^{\circ} \mathrm{C}$ is limited by the loss of body heat at a rate which exceeds heat production. The internal temperature gradient cannot be maintained, and the rectal temperature falls at a rate which becomes increasingly faster, the lower the water temperature [10,11].

We report the case of an open-water ultra-swimmer who was able to achieve a swim distance of $15 \mathrm{~km}$ within $6 \mathrm{~h}$ and $2 \mathrm{~min}$ while swimming at a speed of 2.48 $\mathrm{km} / \mathrm{h}$ in water of $9.9^{\circ} \mathrm{C}$. Body core (rectum) and body surface temperature at the extremities (forearm and calf) were continuously recorded. The swimmer intended to swim as long as possible in water of $9.9^{\circ} \mathrm{C}$, but based upon existing literature, we hypothesized that (1) he would not be able to swim for longer than approximately $60 \mathrm{~min}$ and that (2) he would suffer from both severe hypothermia and afterdrop as has been described in athletes swimming in warmer water $[3,8]$.

\section{Case presentation Subject}

Our subject was an experienced open-water ultra swimmer (53 years old, $110.5 \mathrm{~kg}$ body mass, $1.76 \mathrm{~m}$ body height, and a BMI of $35.7 \mathrm{~kg} / \mathrm{m}^{2}$ ). The experiment was approved by the ethical committee of the Kanton, St. Gallen, Switzerland. The swimmer has a broad experience in open-water ultra-swimming. He completed in 2009 the 26.4- $\mathrm{km}$ swim in Lake Zurich within $11 \mathrm{~h}$ and $1 \mathrm{~min}$. In 2010, he crossed the English Channel in a team relay. In July 2011, he crossed the Great Belt between Germany and Denmark, swimming from Germany to Denmark and back to Germany with a total distance of $50 \mathrm{~km}$ in water of approximately $16^{\circ} \mathrm{C}$ within $19 \mathrm{~h}$ and $15 \mathrm{~min}$. In 2010 and 2011, he completed in total fourteen 24-h swims in pools where he achieved distances up to $53 \mathrm{~km}$. For this specific cold water swim, he started preparing in January 2012 with open-water swims. The first swim was in January 21 in water of $1.7^{\circ} \mathrm{C}$ where he achieved $1 \mathrm{~km}$ in 32 min. With increasing temperature, he could increase the length of the swim distance, leading to a swim time of 1 $\mathrm{km}$ for $28 \mathrm{~min}$ in water of $4.2^{\circ} \mathrm{C}$ and $33 \mathrm{~min}$ in water of $4.7^{\circ} \mathrm{C}$. In addition to the open-water swims, he trained in a heated $\left(25^{\circ} \mathrm{C}\right)$ indoor pool where he completed training units between 4 and $10 \mathrm{~km}$ at a mean speed of approximately $2.8 \mathrm{~km} / \mathrm{h}$.

\section{The event}

The athlete started on 7 April 2012 at 2:00 a.m. in the harbor of Lindau at the Lake Constance, Germany. He was followed by a large motor boat called 'Seewolf' and supported by a little boat called 'Delfin'. On the Delfin, a crew of three people was close to the swimmer. Two experienced divers were ready for immediate rescue, if needed. On the Seewolf, a medical team with full equipment for reanimation including a defibrillator was in contact with the crew on the Delfin via radio. The support crew on the Delfin provided in regular intervals of 30 to $45 \mathrm{~min}$ a standardized carbohydrate gel, the 'Hammer Gel' (www.hammergel.de), with water containing $61 \mathrm{~g}$ of carbohydrates per $100 \mathrm{~g}$ of gel as a drink in a small bottle.

\section{Measurements and calculations}

Before the start of the swim, anthropometric characteristics such as body mass, body height, the circumferences of the limbs and the thicknesses of skinfolds at the pectoral, mid-axilla, triceps, subscapular, abdominal, suprailiac, front thigh, and medial calf sites were measured. The circumferences of the limbs as well as all skinfold thicknesses were measured on the right side of the body. Based on these data, body mass index, percent body fat, fat mass, and skeletal muscle mass, using anthropometric methods, were calculated. Body mass was measured using a commercial balance (Beurer BF 15, Beurer, Ulm, Germany) with a precision of $0.1 \mathrm{~kg}$. Body height was determined using a stadiometer with a precision of 1.0 $\mathrm{cm}$. The circumferences of the limbs were measured using a nonelastic tape measure (KaWe CE, Kirchner \& Wilhelm GmbH + Co. KG, Asperg, Germany) with a precision of $0.1 \mathrm{~cm}$. The circumference of the upper arm was measured at mid-arm; the circumference of the thigh was taken at mid-thigh, and the circumference of the calf was measured at maximum girth. All skinfold data were obtained using a skinfold caliper (GPM-Hautfaltenmessgerät, Siber \& Hegner, Zurich, Switzerland) and recorded to the nearest $0.2 \mathrm{~mm}$. The skinfold measurements were taken once for all skinfold sites. The anatomical sites for the measurements of skinfold thicknesses were pectoral (anterior axillary line), mid-axilla (vertical), triceps (in the middle of the upper arm), subscapular (at the angulus inferior scapulae), abdominal (vertical, right to the navel), suprailiac (at the anterior axillary line), front thigh (mid-thigh), and medial calf (maximum girth). The investigator identified the correct anatomical site using an orientation with finger- and handbreadth from prominent anatomical sites, such as a prominent protuberance or insertion of a tendon. The procedure was performed three times, and the mean of the three measurements was used for the analyses. The available time for taking the skinfold measurements was 
standardized to ensure reliability. According to Becque et al. [12], readings were performed $4 \mathrm{~s}$ after applying the caliper. One trained investigator took all the skinfold measurements, as inter-tester variability is a major source of imprecision in skinfold measurements. Intraand inter-investigator agreement was assessed from 27 male runners prior to an ultra-marathon, based on measurements taken by two experienced primary care physicians [13]. Intra-class correlation (ICC) within the two investigators was excellent for all anatomical measurement sites and for various summary measurements of skinfold thicknesses. Agreement tended to be higher within than between investigators, but it still reached excellent reliability $(\mathrm{ICC}>0.9)$ for the summary measurements of skinfold thicknesses. ICC for investigator 1 versus investigator 1 and for investigator 2 versus investigator 2 for the single skinfold thicknesses were between 0.98 and 0.99 , respectively. For the sum of seven and eight skinfolds, respectively, ICC was 0.99 . For the sum of eight skinfolds for investigator 1 , bias (i.e., average difference between investigator 1 and investigator 2) was $-0.515 \mathrm{~mm}$, and standard deviation of the average difference was $1.492 \mathrm{~mm}$; 95\% limits of agreement were between -3.439 and $2.409 \mathrm{~mm}$. Percent body fat was estimated using the anthropometric formula according to Ball et al. [14] for males with percent bodyfat = $0.465+0.180 \times(\Sigma 7 \mathrm{SF})-0.0002406 \times(\Sigma 7 \mathrm{SF})^{2}+0.0661 \times$ (age), where $\Sigma 7$ SF is the sum of seven skinfold thickness of the pectoralis, axilla, triceps, subscapular, abdomen, suprailiac, and thigh in millimeters and age in years. The predicted residual sum of squares (PRESS) $r^{2}$ was high (0.90), and the PRESS standard error of estimates (SEE) was excellent (2.2\% at the mean) for the equation when applied to a sample of 160 men. Fat mass was estimated using the equations from Stewart and Hannan [15] for male athletes: Fat mass $(\mathrm{g})=331.5 \times$ (abdominal skin - fold thickness) $+356.2 \times($ thigh skin fold thickness $)+111.9 \times$ (body mass $)-9,108$. The coefficient of determination was 0.82 , and the standard error of the estimate was $1,843 \mathrm{~g}$, which is equivalent to $2.4 \%$ for a typical athlete in the sample. Skeletal muscle mass (SMM) was estimated using the formula of Lee et al. [16] with $\mathrm{SMM}=\mathrm{Ht} \times\left(0.00744 \times \mathrm{CAG}^{2}+\right.$ $\left.0.00088 \times \mathrm{CTG}^{2}+0.00441 \times \mathrm{CCG}^{2}\right)+2.4 \times \mathrm{sex}-0.048 \times$ age + race +7.8 where $\mathrm{Ht}=$ height, $\mathrm{CAG}=$ skinfold corrected upper arm girth, CTG = skinfold-corrected thigh girth, CCG = skinfold-corrected calf girth, sex $=1$ for male; age is in years, and race $=0$ for white men and 1 for black men. This equation was validated using magnetic resonance imagining (MRI) to determine the skeletal muscle mass. There was a high correlation between the predicted skeletal muscle mass and the MRImeasured skeletal muscle mass $\left(r^{2}=0.83, P<0.0001\right.$, SEE
$=2.9 \mathrm{~kg}$ ). The correlation between the measured and the predicted SMM difference and the measured SMM was significant $\left(r^{2}=0.90, P=0.009\right)$. In order to compare skinfold thicknesses with the reported data from Keatinge et al. [6], we measured skinfold thickness over the biceps, at the lower corner of the scapula, at the costal margin below the midpoint of the clavicle, and the abdomen 50 $\mathrm{mm}$ below and lateral to the umbilicus.

Temperature was continuously measured as body core temperature in the rectum and as body surface temperature at the left forearm and the right calf using Endotherm $^{\circledR}$ (www.endotherm.ch). These thermoelectric probes measure temperatures from $-40^{\circ} \mathrm{C}$ to $85^{\circ} \mathrm{C}$ with a resolution of $0.0625^{\circ} \mathrm{C}$ and a precision of $0.1^{\circ} \mathrm{C}$. The probes were programmed to take one measurement every $12 \mathrm{~s}$ (five measurements per minute) and were applied $10 \mathrm{~min}$ before the start of the swim in a heated room of $20^{\circ} \mathrm{C}$ located around $100 \mathrm{~m}$ apart from the start of the swim. The probe in the rectum was inserted using a protective container provided by the manufacturer. At the forearm and the calf, the probe was fixed on a neoprene belt of $3 \mathrm{~mm}$ in thickness and $8 \mathrm{~cm}$ in breadth at the forearm and $12 \mathrm{~cm}$ at the calf, and then fixed with a plastic tape. Energy intake during the swim was estimated using the information on the product supplied by the support crew. Energy expenditure was estimated using a stepwise calculation using body mass, mean velocity, and time spent during performance [17]. The completed distance was continuously recorded on the Seewolf using the global positioning system. Water temperature was measured continuously using the onboard thermometer of the Seewolf. Air temperature was provided by the local weather station (www.wetter-lindau.de).

\section{Results}

Table 1 presents the anthropometric characteristics of the swimmer. The mean of the four skinfold thicknesses over biceps, at the lower corner of the scapula, at costal margin below the midpoint of the clavicle, and the abdomen $50 \mathrm{~mm}$ below and lateral to the umbilicus was 33.4 $\mathrm{mm}$. The water temperature in the lake varied between $9.8^{\circ} \mathrm{C}$ and $10.0^{\circ} \mathrm{C}$ with a mean of $9.9^{\circ} \mathrm{C}$ during the whole period. Air temperature was $11.3^{\circ} \mathrm{C}$ at the start and dropped to $9.5^{\circ} \mathrm{C}$ toward the end of the swim. In the last hour of the swim, some heavy rain was falling and a sharp wind from west was blowing. The swimmer achieved a total distance of $15 \mathrm{~km}$ within $6 \mathrm{~h} 02 \mathrm{~min}$ while swimming at a mean speed of $2.48 \mathrm{~km} / \mathrm{h}$, equal to $0.69 \mathrm{~m} / \mathrm{s}$. After two hours of swimming, he suffered from cramps in the right calf. After two hours and a half, he had problems to urinate. After four hours, he felt very cold and suffered from shivering. During the swim, he 
Table 1 Anthropometric characteristics of the subject

\begin{tabular}{|c|c|c|}
\hline Characteristic & & Value \\
\hline Age (years) & & 53 \\
\hline Body mass (kg) & & 110.5 \\
\hline Body height (m) & & 1.76 \\
\hline Body mass index $\left(\mathrm{kg} / \mathrm{m}^{2}\right)$ & & 35.7 \\
\hline \multirow[t]{3}{*}{ Circumferences } & Upper arm $(\mathrm{cm})$ & 36.7 \\
\hline & Thigh (cm) & 63.9 \\
\hline & Calf $(\mathrm{cm})$ & 43.6 \\
\hline \multirow[t]{12}{*}{ Skinfold thicknesses } & Pectoral (mm) & 36.4 \\
\hline & Clavicula (mm) & 30.2 \\
\hline & Biceps (mm) & 11.1 \\
\hline & Axilla (mm) & 39.2 \\
\hline & Triceps (mm) & 14.2 \\
\hline & Subscapular (mm) & 46.2 \\
\hline & Forearm (mm) & 18.3 \\
\hline & Abdominal (mm) & 46.2 \\
\hline & Suprailiac (mm) & 41.6 \\
\hline & Thigh (mm) & 44.4 \\
\hline & Calf $(\mathrm{mm})$ & 42.6 \\
\hline & Sum (mm) & 310.2 \\
\hline Percent body fat (\%) & & 34.9 \\
\hline Estimated fat mass $(\mathrm{kg})$ & & 34.4 \\
\hline Estimated skeletal muscle mass $(\mathrm{kg})$ & & 38.1 \\
\hline
\end{tabular}

expended a total energy of $\sim 2,530 \mathrm{kcal}$. He consumed a total of $\sim 213 \mathrm{~g}$ of carbohydrates with a total energy content of $\sim 510 \mathrm{kcal}$ and an energy deficit of $\sim 2,020 \mathrm{kcal}$ resulted.

Figure 1 shows the development of the temperatures measured in the rectum (body core), at the forearm, and at the calf. At the start of the swim, the body core temperature was at $37.8^{\circ} \mathrm{C}$. It increased to a maximum of $38.1^{\circ} \mathrm{C}$ after approximately $20 \mathrm{~min}$ of swimming and then decreased continuously to $36.3^{\circ} \mathrm{C}$ upon finishing the swim. The lowest body core temperature occurred between 35 and 60 min after finishing the swim with $36.0^{\circ} \mathrm{C}$. After $60 \mathrm{~min}$, the body core temperature started to rise continuously, reaching $36.5^{\circ} \mathrm{C} 2 \mathrm{~h}$ after getting out of the water. The temperature at the forearm dropped to $19.6^{\circ} \mathrm{C}$ after $36 \mathrm{~min}$ of swimming and decreased to $19.4^{\circ} \mathrm{C}$ at the end of the swim. The lowest temperature at the forearm was $17.6^{\circ} \mathrm{C}$ measured approximately $47 \mathrm{~min}$ before he stopped swimming. The temperature at the calf dropped to $13.0^{\circ} \mathrm{C}$ measured after approximately $24 \mathrm{~min}$ and decreased to $11.9^{\circ} \mathrm{C}$ at the end of the swim. The lowest temperature was $11.1^{\circ} \mathrm{C}$ measured at approximately $108 \mathrm{~min}$ after the start. At both the forearm and the calf, the skin temperature continuously increased after the swim.

\section{Discussion}

The most important finding of this investigation was that body core temperature initially increased and then

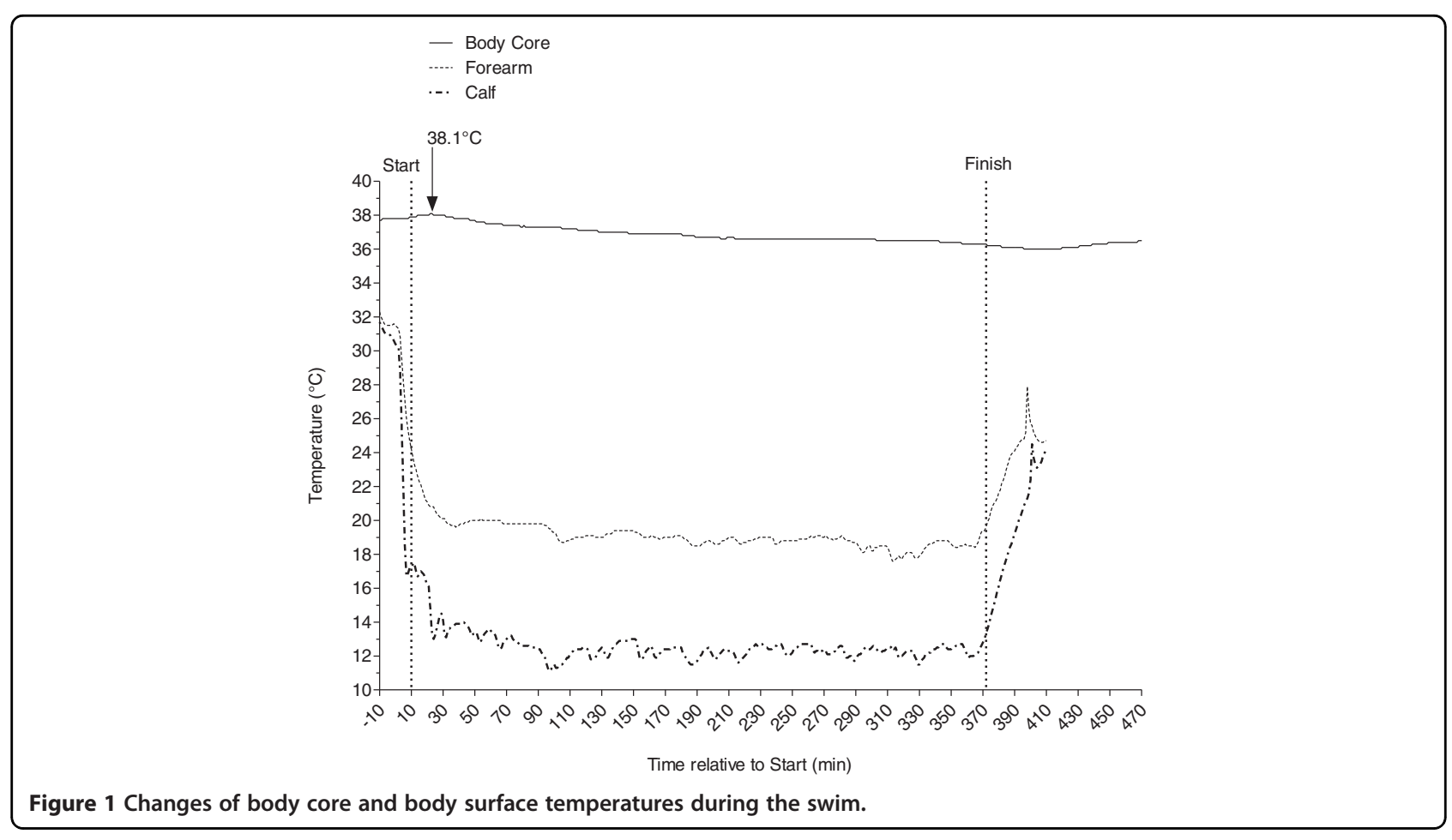


slowly decreased to $36.3^{\circ} \mathrm{C}$ by the end of the swim. By definition, this cold water swimmer did not suffer from hypothermia $[3,8]$. Using an equation to predict the survival time of man in cold water with $15+7.2 /(0.0785-$ $0.0034 \times$ water temperature) [18], the swimmer should have died after $2 \mathrm{~h}$ and $55 \mathrm{~min}$ in water of $9.9^{\circ} \mathrm{C}$. Death, however, could also have occurred after the swim. It has been shown that persons evacuated from cold water died in the post-immersion period $[19,20]$. Ventricular fibrillation is likely during that period, and cardiac failure may follow [21].

\section{Body core temperature and hypothermia}

The normal core body temperature of a healthy, resting adult human being is stated to be between $36.1^{\circ} \mathrm{C}$ and $37.8^{\circ} \mathrm{C}$ [22]. Although the body temperature of an individual can vary, a healthy human body can maintain a fairly consistent body temperature between $36.8^{\circ} \mathrm{C}$ and $37.0^{\circ} \mathrm{C}[23,24]$. There are different values for normal temperatures regarding oral, rectal, tympanic, and axillary body temperatures [24]. The range for oral temperature is $33.2^{\circ} \mathrm{C}-38.2^{\circ} \mathrm{C}$, for rectal $34.4^{\circ} \mathrm{C}-37.8^{\circ} \mathrm{C}$, for tympanic $35.4^{\circ} \mathrm{C}-37.8^{\circ} \mathrm{C}$, and for axillary $35.5^{\circ} \mathrm{C}-$ $37.0^{\circ} \mathrm{C}$. The range for oral temperature in men and women is $35.7^{\circ} \mathrm{C}-37.7^{\circ} \mathrm{C}$ and $33.2^{\circ} \mathrm{C}-38.1^{\circ} \mathrm{C}$, for rectal $36.7^{\circ} \mathrm{C}-37.5^{\circ} \mathrm{C}$ and $36.8^{\circ} \mathrm{C}-37.1^{\circ} \mathrm{C}$, and for tympanic $35.5^{\circ} \mathrm{C}-37.5$ and $35.7^{\circ} \mathrm{C}-37.5^{\circ} \mathrm{C}$, respectively [24]. Hypothermia is defined as any body temperature below $35.0^{\circ} \mathrm{C}[4,8,9]$. It is subdivided into four different degrees such as mild hypothermia $\left(32^{\circ} \mathrm{C}-35^{\circ} \mathrm{C}\right)$, moderate hypothermia $\left(28^{\circ} \mathrm{C}-32^{\circ} \mathrm{C}\right)$, severe hypothermia $\left(20^{\circ} \mathrm{C}-\right.$ $28^{\circ} \mathrm{C}$ ), and profound hypothermia at $<20^{\circ} \mathrm{C}$ [25]. Respecting these definitions, our swimmer was able to maintain his body core temperature within the normal range without suffering hypothermia.

\section{Skinfold thicknesses and body fat}

The most likely reason for the finding that our swimmer was able to swim for $6 \mathrm{~h}$ and $2 \mathrm{~min}$ in water of $9.9^{\circ} \mathrm{C}$ was his high fat mass $[5,26,27]$, his high body mass index [8], and his experience in open-water ultra-swimming in cold water [7]. In a field study on eight swimmers in the study of Keatinge et al. [6], the swimmers' body core temperatures dropped by $1.94^{\circ} \mathrm{C}$ after $52.3 \mathrm{~min}$. The mean duration of the swim was related to the mean skinfold thickness of the recorded four skinfold thicknesses. The present swimmer had a mean skinfold thickness of $33.4 \mathrm{~mm}$ for the four skinfolds. In contrast to the skinfold thickness of $13.64 \mathrm{~mm}$ of the eight swimmers in Keatinge et al. [6], the mean of the four skinfolds was approximately 2.4 times higher in the present swimmer. Following Pugh and Edholm [28], the most important and certainly the clearest answer to the question of whether the heat loss in the Channel swimmers was diminished owing to their body: all the Channel swimmers were fat and many of them were grossly fat. Body fat provided an insulator to reduce heat loss [28]. Heat is produced and stored in the body core and flows down the thermal gradients' esophageal temperature-skin temperature and skin temperaturewater temperature [29]. The flow of heat from the core to the skin can be affected by the characteristics of two parallel resistors: one is a fixed resistance which is the layer of body fat, and the other is a variable resistance which represents the peripheral circulation [29].

A relationship between individual skinfold thickness and change in esophageal temperature during submaximal swimming in $18^{\circ} \mathrm{C}$ and $26^{\circ} \mathrm{C}$ has been shown [29-31]. Internal temperature changes after $20 \mathrm{~min}$ of submaximal swimming were related to water temperature, swimming intensity, and body insulation [29]. Mean skin temperatures were related to both water temperature and water velocity during rest and to water temperature during swimming [29]. Furthermore, the human fat is a better insulator than the human muscle [32]. Fat becomes an effective means of body insulation at high rates of heat flow [33]. This is the situation which prevails during long-distance swimming since swimmers have a high heat production and are immersed in cold water. Under such conditions, each millimeter of subcutaneous body fat will sustain a temperature difference of $1.67^{\circ} \mathrm{C}$ [33]. The importance of thick skinfolds seems to depend upon the temperature of the water. Pugh et al. [33] reported the skinfold thickness of the Channel swimmers at $15.5^{\circ} \mathrm{C}-18^{\circ} \mathrm{C}$ and their performance. The winners tended to be less fat than the slower swimmers. Cold tolerance in long-distance swimmers is complex and may involve a factor related to habituation [27,34]. Cold-accustomed swimmers tolerated immersion in cold water better than unaccustomed swimmers [34]. Golden et al. [27] described three swimmers who competed in Lake Windermere. When swimming in the lake, the two cold-accustomed swimmers were faster than the swimmer with less tolerance, although he had a greater mean skinfold. Modern competitive distance swimmers in open water seem to be relatively lean [27].

We placed one thermoelectric probe at the forearm and one thermoelectric probe at the calf to measure the temperature at the surface of the body. We were surprised that we found a difference of approximately $7^{\circ} \mathrm{C}$ between the surface temperature at the calf and the forearm. The most probable explanation would be the difference in the thickness of the skinfolds at these two sites. At the forearm, the temperature remained rather unchanged at approximately $19^{\circ} \mathrm{C}$; at the calf, the temperature remained at approximately $12^{\circ} \mathrm{C}$. The skinfold thickness at the forearm was $18.3 \mathrm{~mm}$; at the calf, it was $42.6 \mathrm{~mm}$. The thicker skinfold at the calf site showed obviously a better isolation 
against the cold water than the thinner skinfold thickness at the forearm site.

The estimated fat mass of $34.4 \mathrm{~kg}$ was most probably a very useful isolation towards the cold water $[35,36]$. Also, a high fat mass may increase buoyancy in water [5]. In a case report with two swimmers in ice-cold water, the swimmer with a sum of eight skinfolds of $139.8 \mathrm{~mm}$ was able to swim for $42 \mathrm{~min}$ in water of $4^{\circ} \mathrm{C}$, whereas the other swimmer with a lower sum of $124.8 \mathrm{~mm}$ stopped the swim after 23 min [7]. Petrofsky and Laymon [37] showed that subjects with high body fat changed their deep tissue temperatures much slower than thin subjects when the lower body was immersed in water at $42^{\circ} \mathrm{C}, 37^{\circ} \mathrm{C}, 34^{\circ} \mathrm{C}$, $27^{\circ} \mathrm{C}, 24^{\circ} \mathrm{C}$, and $0^{\circ} \mathrm{C}$ for $20 \mathrm{~min}$. Keatinge [35] demonstrated that the fattest man suffered relatively small falls in rectal temperature at both $5^{\circ} \mathrm{C}$ and $15^{\circ} \mathrm{C}$ cold water compared with thinner men, and Cannon and Keatinge [38] reported that fat men could reduce their loss of heat more than thin men in the cold. Keatinge [36] showed a linear relationship between rectal temperatures and mean skinfold thickness when subjects were immersed for $30 \mathrm{~min}$ in water of $15^{\circ} \mathrm{C}$.

Apart from fat mass, a high body mass index may also help humans to stay longer in cold water. Nuckton et al. [8] demonstrated that body mass index correlated with the lowest recorded body core temperature and afterdrop duration when swimming in water of $11.7^{\circ} \mathrm{C}$. An important finding was that body core temperature rose to $38.1^{\circ} \mathrm{C}$ after $20 \mathrm{~min}$ of swimming, and the lowest body core temperature was found between 35 and $60 \mathrm{~min}$ after finishing the swim with $36.0^{\circ} \mathrm{C}$. Upon finishing the swim, the body core temperature was at $36.3^{\circ} \mathrm{C}$. Thus, the decrease by $0.3^{\circ} \mathrm{C}$ corresponds to an afterdrop, which is defined as continued cooling following removal from cold stress [8]. The occurrence of an afterdrop appears not to depend upon the existence of a circulation but may be explained by a thermal conduction mechanism [39]. Afterdrop seems to be more frequent than hypothermia in cold water swimmers. Nuckton et al. [8] investigated 11 subjects in the New Year's Day Alcatraz Swim. While 5 of the 11 subjects suffered from hypothermia, afterdrop was seen in 10 of the 11 subjects.

\section{Conclusions}

The present case report shows that it is possible to swim for $6 \mathrm{~h}$ in water of $9.9^{\circ} \mathrm{C}$ without signs of hypothermia. The high body mass index, high body fat, previous experience with cold habituation, and specific preparation of the swimmer are the most probable explanations for these findings.

\section{Consent}

Written informed consent was obtained from the athlete for publication of this case report. A copy of the written informed consent is available for review by the Editorin-Chief of this journal.

\section{Competing interests}

The authors declare that they have no competing interests.

\section{Authors' contributions}

CAR collected the data and drafted the manuscript. BK and TR helped draft the manuscript. All authors read and approved the final manuscript.

\section{Acknowledgments}

We would like to thank EndoTherm GmbH, Arlesheim, Switzerland for providing the thermoelectric probes Endotherm ${ }^{\circledR}$.

Received: 22 May 2012 Accepted: 19 September 2012 Published: 1 November 2012

\section{References}

1. Nevill AM, Whyte GP, Holder RL, Peyrebrune M: Are there limits to swimming world records? Int J Sports Med 2007, 28:1012-1017.

2. Eichenberger $E$, Knechtle B, Knechtle P, Rüst CA, Rosemann T, Lepers R: No gender difference in peak performance in ultra-endurance swimming performance-analysis of the 'Zurich 12-h Swim' from 1996 to 2010. Chinese Journal of Physiology 55(5): 346-351, 2012.

3. Brannigan D, Rogers $I R$, Jacobs I, Montgomery A, Williams A, Khangure $\mathrm{N}$ : Hypothermia is a significant medical risk of mass participation long-distance open water swimming. Wilderness Environ Med 2009, 20:14-18.

4. Castro RR, Mendes FS, Nobrega AC: Risk of hypothermia in a new Olympic event: the 10-km marathon swim. Clinics (Sao Paulo) 2009, 64:351-356.

5. Keatinge WR, Prys-Roberts C, Cooper KE, Honour AJ, Haight J: Sudden failure of swimming in cold water. Br Med J 1969, 22:480-483.

6. Keatinge WR, Khartchenko M, Lando N, Lioutov V: Hypothermia during sports swimming in water below 11 degrees C. Br J Sports Med 2001, 35:352-353.

7. Knechtle $B$, Christinger N, Kohler $G$, Knechtle $P$, Rosemann $T$ : Swimming in ice cold water. Ir J Med Sci 2009, 178:507-511.

8. Nuckton TJ, Claman DM, Goldreich D, Wendt FC, Nuckton JG: Hypothermia and afterdrop following open water swimming: the Alcatraz/San Francisco Swim Study. Am J Emerg Med 2000, 18:703-707.

9. Tipton M, Eglin C, Gennser M, Golden F: Immersion deaths and deterioration in swimming performance in cold water. Lancet 1999, 354:626-629.

10. Pugh LG, Edholm OG: The physiology of channel swimmers. Lancet 1955, 269:761-768.

11. Molnar GW: Survival of hypothermia by men immersed in the ocean. J Am Med Assoc 1946, 131:1046-1050.

12. Becque MD, Katch VL, Moffatt RJ: Time course of skin-plus-fat compression in males and females. Hum Biol 1986, 58:33-42.

13. Knechtle B, Joleska I, Wirth A, Knechtle P, Rosemann T, Senn O: Intra- and inter-judge reliabilities in measuring the skin-fold thicknesses of ultra runners under field conditions. Percept Mot Skills 2010, 111:105-106.

14. Ball SD, Altena TS, Swan PD: Comparison of anthropometry to DXA: a new prediction equation for men. Eur J Clin Nutr 2004, 58:1525-1531.

15. Stewart AD, Hannan WJ: Prediction of fat mass and fat-free mass in male athletes using dual $\mathrm{X}$-ray absorptiometry as the reference method. J Sports Sci 2000, 18:263-274.

16. Lee RC, Wang Z, Heo M, Ross R, Janssen I, Heymsfield SB: Total-body skeletal muscle mass: development and cross-validation of anthropometric prediction models. Am J Clin Nutr 2000, 72:796-803.

17. Williams MH: Nutrition for Fitness and Sport. 4th edition. Madison: Brown \& Benchmark Publishers; 1995.

18. Hayward JS, Eckerson JD, Collis ML: Thermal balance and survival time prediction of man in cold water. Can J Physiol Pharmacol 1975, 53:21-32.

19. Golden FS, Hervey GR, Tipton MJ: Circum-rescue collapse: collapse, sometimes fatal, associated with rescue of immersion victims. J R Nav Med Serv 1991, 77:139-149.

20. Golden FS: Problems of immersion. Br J Hosp Med 1980, 23:371-383.

21. Golden FS: Death after rescue from immersion in cold water. J R Nav Med Serv 1973, 59:5-8. 
22. Simmers L: Diversified Health Occupations. 2nd edition. New York: Delmar; 1988:150-151.

23. Mackowiak PA, Wasserman SS, Levine MM: A critical appraisal of 98.6 degrees $F$, the upper limit of the normal body temperature, and other legacies of Carl Reinhold August Wunderlich. JAMA 1992, 268:1578-1580.

24. Sund-Levander M, Forsberg C, Wahren LK: Normal oral, rectal, tympanic and axillary body temperature in adult men and women: a systematic literature review. Scand J Caring Sci 2002, 16:122-128.

25. Marx J: Rosen's Emergency Medicine: Concepts And Clinical Practice. Philadelphia: Mosby/Elsevier; 2006.

26. Choi JS, Ahn DW, Choi JK, Kim KR, Park YS: Thermal balance of man in water: prediction of deep body temperature change. Appl Human Sci 1996, 15:161-167.

27. Golden FS, Hampton IF, Smith D: Lean long distance swimmers. J R Nav Med Serv 1980, 66:26-30

28. Pugh LG, Edholm OG: The physiology of channel swimmers. 1955. Wilderness Environ Med 2004, 15:40-41.

29. Nadel ER, Holmér I, Bergh U, Astrand PO, Stolwijk JA: Energy exchanges of swimming man. J Appl Physiol 1974, 36:465-471.

30. Holmér I: Physiology of swimming man. Acta Physiol Scand Supp/ 1974, 407:1-55.

31. Holmér I, Bergh U: Metabolic and thermal response to swimming in water at varying temperatures. J Appl Physiol 1974, 37:702-705.

32. Hatfield HS, Pugh LG: Thermal conductivity of human fat and muscle. Nature 1951, 168:918-919.

33. Pugh LG, Edholm OG, Fox RH, Wolff HS, Hervey GR, Hammond WM, Tanner $J M$, Whitehouse RH: A physiological study of channel swimming. Clin Sci 1960, 19:257-273.

34. Golden FS, Hampton IF, Smith D: Cold tolerance in long-distance swimmers [proceedings]. J Physiol 1979, 290:48P-49P.

35. Keatinge WR: The effect of work and clothing on the maintenance of the body temperature in water. Q J Exp Physiol Cogn Med Sci 1961, 46:69-82.

36. Keatinge WR: The effects of subcutaneous fat and of previous exposure to cold on the body temperature, peripheral blood flow and metabolic rate of men in cold water. J Physiol 1960, 153:166-178.

37. Petrofsky JS, Laymon M: Heat transfer to deep tissue: the effect of body fat and heating modality. J Med Eng Technol 2009, 33:337-348.

38. Cannon P, Keatinge WR: The metabolic rate and heat loss of fat and thin men in heat balance in cold and warm water. J Physiol 1960, 154:329-344.

39. Golden FS, Hervey GR: The mechanism of the after-drop following immersion hypothermia in pigs [proceedings]. J Physiol 1977, 272:26P-27P.

doi:10.1186/2046-7648-1-8

Cite this article as: Rüst et al:: Changes in body core and body surface temperatures during prolonged swimming in water of $10^{\circ} \mathrm{C}$-a case report. Extreme Physiology \& Medicine 2012 1:8

\section{Submit your next manuscript to BioMed Central and take full advantage of:}

- Convenient online submission

- Thorough peer review

- No space constraints or color figure charges

- Immediate publication on acceptance

- Inclusion in PubMed, CAS, Scopus and Google Scholar

- Research which is freely available for redistribution 